\title{
Characterization of a $\mathrm{G}_{\mathrm{i}}$-protein from Trypanosoma cruzi epimastigote membranes
}

\author{
Omar A. COSO, Alberto DÍAZ AÑEL, Horacio MARTINETTO, Jorge P. MUSCHIETTI, Marcelo KAZANIETZ, \\ Diego FRAIDENRAICH, Héctor N. TORRES and Mirtha M. FLAWIA* \\ Instituto de Investigaciones en Ingeniería Genética y Biología Molecular and Facultad de Ciencias Exactas y Naturales, \\ Obligado 2490, 1428 Buenos Aires, Argentina
}

\begin{abstract}
A guanosine $5^{\prime}-\left[\gamma-\left[{ }^{35}\right.\right.$ S $]$ thio $]$ triphosphate-binding activity was detergent-extracted from Trypanosoma cruzi membranes. This binding activity was co-eluted from gel-filtration columns with a factor which, in a heterologous reconstitution system, blocks glucagon stimulation of adenylate cyclase activity in liver membranes. ADP-ribosylation of these membranes by pertussis toxin eliminated this blocking capacity. Incubation of $T$. cruzi membranes with activated pertussis toxin and [adenylate $\left.{ }^{32} \mathrm{P}\right] \mathrm{NAD}^{+}$led to the incorporation of radioactivity into a labelled product with an apparent $M_{\mathrm{r}}$ of approx: 43000. Crude membranes were electrophoresed on SDS/polyacrylamide gels and analysed, by Western blotting, with GA/1 anti- $\alpha_{\text {common }}, \mathrm{AS} / 7$ anti- $\alpha_{t}$, anti- $\alpha_{11}$ and anti- $\alpha_{i 2}$ polyclonal antibodies. These procedures led to the identification of a specific polypeptide band of about $43 \mathrm{kDa}$. Another polypeptide reacting with the $\mathrm{SW} / 1$ anti- $\beta$ antibody, of about $30 \mathrm{kDa}$, was also detected in the membrane fraction.
\end{abstract}

\section{INTRODUCTION}

G-proteins involved in transmembrane signalling are heterotrimers composed of $\alpha, \beta$ and $\gamma$ subunits, with molecular masses of $40-45,35-36$ and 5-8 $\mathrm{kDa}$ respectively. The $\alpha$ subunits bind and hydrolyse GTP; they are substrates for ADP-ribosylation by bacterial toxins, and they carry the specificity for receptors and effectors (Birnbaumer et al., 1990).

There are several structural and functional differences between $\alpha$ subunits. The mammalian genome codes for several types of $\alpha$ subunits, including four $\alpha_{s}$, three $\alpha_{i}$, one $\alpha_{0}$, one $\alpha_{t}$ and one $\alpha_{\text {olf }}$ (for review, see Birnbaumer et al., 1990). Some of these subunits have well-defined functions: $\alpha_{\mathrm{s}}$ couples stimulatory receptors to adenylate cyclase (Gilman, 1984) and $\mathrm{Ca}^{2+}$ channels (Yatani et al., 1987), $\alpha_{1}$ may be involved in the inhibition of adenylate cyclase (Jakobs et al., 1976) and in the opening of $\mathrm{K}^{+}$channels (Kurachi et al., 1986), $\alpha_{0}$ acts in the closing of $\mathrm{Ca}^{2+}$ channels (Holz et al., 1986), and $\alpha_{\mathrm{t}}$ couples photolysed rhodopsin with the stimulation of cyclic GMP phosphodiesterase activity (Stryer, 1986).

Previous evidence from our laboratory indicates that Trypanosoma cruzi membranes have a $45 \mathrm{kDa}$ polypeptide that can be ADP-ribosylated by cholera toxin. In addition, after electrofusion of $T$. cruzi and lymphoma S49 cyc cells, a heterologous adenylate cyclase is reconstituted that is then activated by isoprenaline or fluoride (Eisenschlos et al., 1986). This strongly suggests the existence in $T$. cruzi membranes of an $\alpha_{\mathrm{s}}$ polypeptide.

The present paper reports evidence for the existence in $T$. cruzi membranes of a $43 \mathrm{kDa}$ polypeptide that shows several functional and immunological properties that are characteristic of $\mathbf{G} \alpha_{1}$ subunits. In addition, results presented here indicate the presence in these membranes of a $30 \mathrm{kDa}$ polypeptide immunoreacting with an antiserum to $\mathrm{G} \beta$-subunit.

\section{MATERIALS AND METHODS}

\section{Materials}

The sources of materials used in this work are given elsewhere (Eisenschlos et al., 1986; Muschietti et al., 1989).

Antisera raised against synthetic peptides that correspond to defined regions of G-protein subunits (Mumby et al., 1986; Goldsmith et al., 1988; Simonds et al., 1989) were kindly provided by Dr. Allen M. Spiegel (National Institutes of Diabetes and Digestive and Kidney Diseases, N.I.H., Bethesda, MD, U.S.A.), Dr. Eduardo Lapetina and Dr. Daniel Altschuler (Wellcome Research Laboratories, Research Triangle Park, NC, U.S.A.), Dr. Lutz Birnbaumer (Baylor College of Medicine, Houston, TX, U.S.A.) and Dr. Alfred G. Gilman (University of Texas, Dallas, TX, U.S.A.). These antisera correspond to the following antigens: AS/7 ( $C$-terminus of $\left.\alpha_{t}, \alpha_{i 1}, \alpha_{i 2}\right)$; SW $/ 1$ ( $C$-terminus of $\beta$-subunit); GA/1 (GTP-binding site; $\left.\alpha_{\text {common }}\right) ; \mathrm{RM} / 1$ ( $N$-terminus of $\alpha_{\mathrm{s}}$ ).

Guanosine $\quad 5^{\prime}-\left[\gamma-\left[{ }^{35} \mathrm{~S}\right]\right.$ thio $]$ triphosphate $\quad\left(\mathrm{GTP}\left[{ }^{35} \mathrm{~S}\right]\right)$ and [adenylate $\left.{ }^{32} \mathrm{P}\right] \mathrm{NAD}^{+}$were purchased from New England $\mathrm{Nu}-$ clear (Boston, MA, U.S.A.), and pertussis toxin was from Sigma Chemical Co. (St. Louis, MO, U.S.A.). A peptide with the $C$ terminal amino acid sequence of $\alpha_{t}, \alpha_{11}$ and $\alpha_{12}$ (KENLKDCGLF) was obtained from Biodynamics (Martinez, Argentina).

\section{Membrane preparation}

Liver plasma membranes were prepared by the procedure of Neville (1968). T. cruzi membranes were prepared as described by Torruella et al. (1986).

\section{Detergent extraction of $T$. cruzi membranes}

Membranes were suspended (10 mg of protein $/ \mathrm{ml}$ ) in $50 \mathrm{~mm}$ Tris $/ \mathrm{HCl}$ buffer, $\mathrm{pH} 7.5$, containing $1 \mathrm{~mm}-\beta$-mercaptoethanol and $1 \%(\mathrm{w} / \mathrm{v})$ sodium cholate, left in ice for $2 \mathrm{~h}$ with magnetic stirring, and centrifuged for $60 \mathrm{~min}$ at $105000 \mathrm{~g}$. The detergent concentration in the extract was lowered by filtration through Ultrogel AcA34. The column $(1.4 \mathrm{~cm} \times 40 \mathrm{~cm})$, equilibrated with $50 \mathrm{~mm}$-Tris $/ \mathrm{HCl}$ buffer, $\mathrm{pH} 7.5$, containing $0.1 \%$ sodium cholate, was loaded with $1.5 \mathrm{ml}$ of the supernatant $(9 \mathrm{mg}$ of protein). Elution $(0.5 \mathrm{ml} / \mathrm{min})$ was performed at $4{ }^{\circ} \mathrm{C} ; 1.5 \mathrm{ml}$ fractions were collected. Fractions with the highest GTP[S]binding activity were pooled and stored at $4{ }^{\circ} \mathrm{C}$ (giving the 'Ultrogel fraction').

\section{GTP-binding assay}

Binding of GTP $\left[{ }^{35} \mathrm{~S}\right]$ to purified protein fractions was carried

* To whom correspondence should be addressed. 

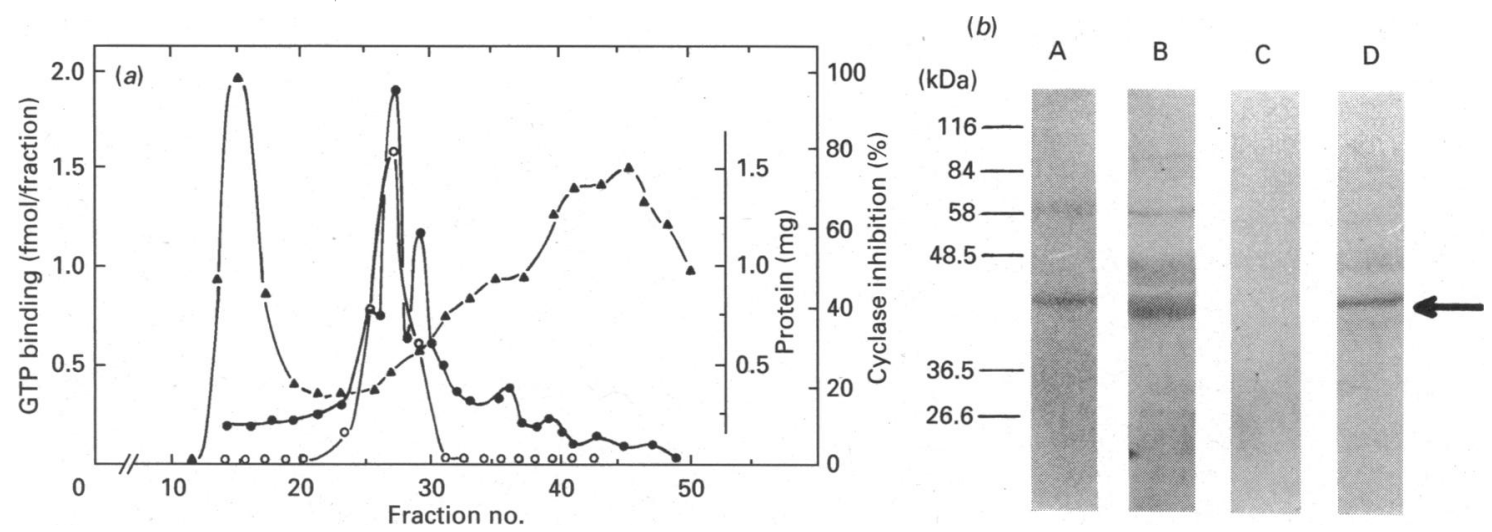

Fig. 1. Gel filtration on Ultrogel AcA34 of a detergent extract of T. cruzi membranes

(a) , GTP binding; $O$, inhibition of liver membrane adenylate cyclase activity; $\Delta$, protein. (b) Immunoreaction of $T$. cruzi polypeptides from membranes (A), total epimastigote extract (B) and Ultrogel fractions 44 (C) and 27 (D) with the antiserum AS/7. Conditions were described in the Materials and methods section.

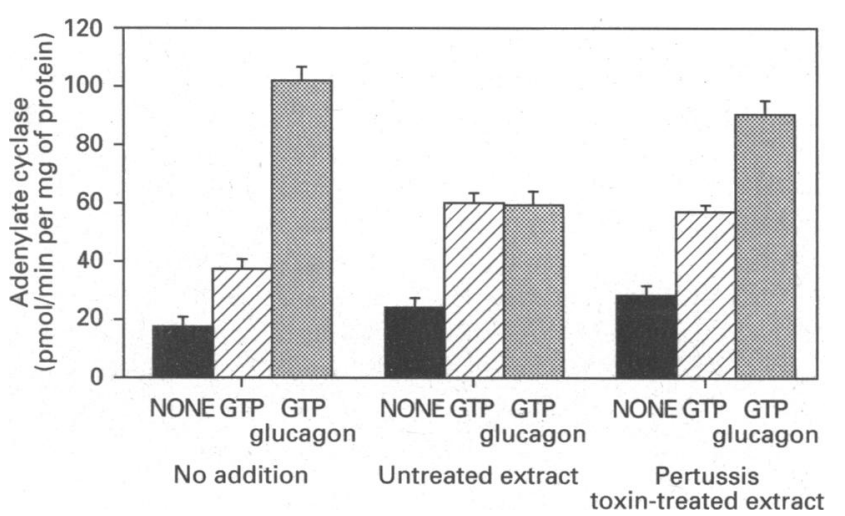

Fig. 2. Effect of detergent extract from $T$. cruzi membranes on the activation by glucagon of liver membrane adenylate cyclase activity

Glucagon and GTP concentrations in the mixtures were $10 \mathrm{nM}$ and $1 \mu \mathrm{M}$ respectively. The experiment was performed in triplicate samples. Bars indicate S.D. Other conditions are described in the Materials and methods section.

out by the procedure of Northup et al. (1982) with the modifications indicated by Waldo et al. (1987). Under the conditions for the assay procedure, GTP binding was proportional to the protein concentration.

\section{$\mathrm{NAD}^{+}$and pertussis-toxin treatment of membrane proteins}

Very fresh $T$. cruzi membranes or bovine rod-outer-segment membranes $(0.1 \mathrm{mg}$ of protein/assay) were incubated for $30 \mathrm{~min}$

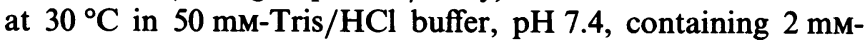
$\mathrm{MgCl}_{2}, 1$ mM-EDTA, $10 \mathrm{~mm}$-dithiothreitol, $0.01 \%$ (v/v) Lubrol, $1 \mathrm{mM}-\mathrm{ATP}, 0.2 \mathrm{mM}-\mathrm{GTP}, 1 \mu \mathrm{M}-\left[\right.$ adenylate $^{32} \mathrm{P}^{3} \mathrm{NAD}^{+}$(sp. radioactivity 40000 c.p.m./pmol) and $12 \mu \mathrm{g}$ of activated pertussis toxin (preincubated at a concentration of $0.4 \mathrm{mg} / \mathrm{ml}$, in the presence of $10 \mathrm{~mm}$-dithiothreitol). Total volume was $0.06 \mathrm{ml}$. After incubation, a $0.025 \mathrm{ml}$ sample was diluted in $0.5 \mathrm{ml}$ of $3 \%$ (w/v) SDS and precipitated by addition of $0.5 \mathrm{ml}$ of cold $30 \%$ (w/v) trichloroacetic acid. The precipitate was collected on nitrocellulose filters, washed five times with $6 \%$ trichloroacetic acid and counted for radioactivity. The rest of the incubation mixture was adjusted to final concentrations of ATP and NAD ${ }^{+}$ of $10 \mathrm{mM}$ and $5 \mathrm{~mm}$ respectively and then subjected to SDS/PAGE. The resolved polypeptides were transferred from the gel to a nitrocellulose membrane, which was further exposed to a radioautographic film.

In the reconstitution experiments, membranes were ADPribosylated as indicated above, except that $10 \mu \mathrm{M}$ unlabelled $\mathrm{NAD}^{+}$was used instead of $\left[{ }^{32} \mathrm{P}\right] \mathrm{NAD}^{+}$. After incubation, the mixtures were dialysed for $3 \mathrm{~h}$ at $4{ }^{\circ} \mathrm{C}$ against $50 \mathrm{mM}$-Tris $/ \mathrm{HCl}$ buffer, $\mathrm{pH} 7.5$, containing $0.1 \%$ sodium cholate. If, after toxin pretreatment in the presence of unlabelled $\mathrm{NAD}^{+}$, the incubation mixture was further incubated in the presence of $\left[{ }^{32} \mathrm{P}_{\mathrm{NAD}}{ }^{+}\right.$, there was no incorporation of radioactivity in the trichloroacetic acid precipitate.

\section{Heterologous reconstitution by using membranes and detergent extracts}

Samples $(20 \mu \mathrm{l})$ of $T$. cruzi 'Ultrogel fraction'. or ADPribosylated membranes (150 $\mu \mathrm{g}$ of protein) were preincubated for $15 \mathrm{~min}$ at $37^{\circ} \mathrm{C}$ with $5 \mu \mathrm{l}$ of liver membranes $(100 \mu \mathrm{g}$ of protein). After that, the mixtures were immediately assayed for adenylate cyclase activity.

\section{Analytical methods}

Adenylate cyclase assays were performed as described elsewhere (Flawiá et al., 1983; Eisenschlos et al., 1986). Protein was determined by the method of Lowry et al. (1951). Procedures for SDS/PAGE of protein samples were described elsewhere (Kornblihtt et al., 1981).

Polypeptide transfer from polyacrylamide gels to nitrocellulose membranes was carried out by electrotransference (KhyseAndersen, 1984). For reaction with antibodies, the membranes after the transfer were blocked with a suspension of non-fat milk (Johnson et al., 1984). After reaction with the corresponding antibody, detection was carried out with the Vectastain ABC-AP kit (Vector Laboratories, Burlingame, CA, U.S.A.), by following the instructions of the manufacturer. Controls were performed either with pre-immune rabbit serum or with $200 \mu \mathrm{M}$ specific peptide. In this latter case conditions were those described by Burstein \& Macara (1989).

\section{RESULTS AND DISCUSSION}

\section{Extraction and functional characterization}

Treatment of $T$. cruzi membranes with a buffer containing $1 \%$ sodium cholate led to the extraction of a GTP $\left.{ }^{35} \mathrm{~S}\right]$-binding activity. Upon gel filtration on an Ultrogel AcA34 column this 


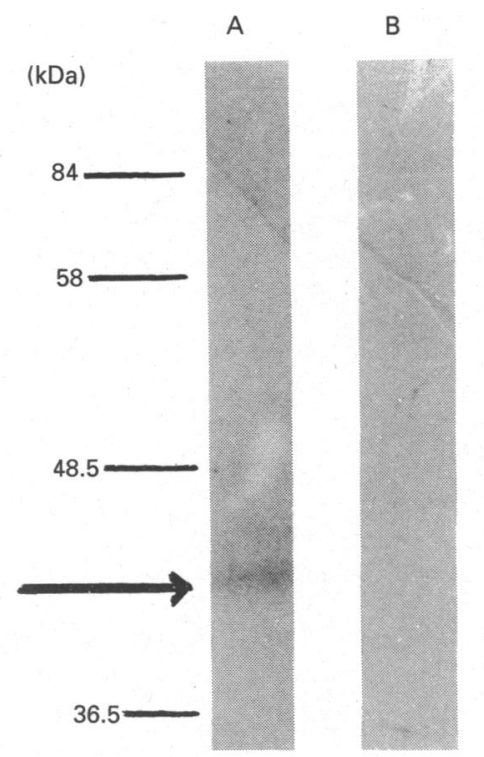

Fig. 3. ADP-ribosylation of $T$. cruzi membranes in the presence of [adenylate- $\left.{ }^{32} \mathbf{P}\right] \mathbf{N A D}^{+}$

SDS/PAGE of $T$. cruzi membranes treated with (A) or without (B) pertussis toxin in the presence of $\left[\right.$ adenylate $\left.{ }^{32} \mathrm{P}\right] \mathrm{NAD}^{+}$. Conditions are described in the Materials and methods section.

binding activity co-eluted with a factor which, in a heterologous reconstitution system, blocked glucagon stimulation of adenylate cyclase activity in liver membranes (Fig. 1a). This capacity to block hormone stimulation of liver adenylate cyclase might be the consequence of a putative $\mathrm{G}_{\mathrm{i}}$-protein extracted from $T$. cruzi membranes. As shown in Fig. 1(b), in crude extracts, membranes and the binding-activity peak fractions a $43 \mathrm{kDa}$ polypeptide band was identified that immunoreacted with the AS/7 anti- $\alpha_{i}$ antibody. This band was not observed in column fractions devoid of GTP[S]-binding activity.

ADP-ribosylation of $G \alpha_{i}$ polypeptides by pertussis toxin decreases their ability to block adenylate cyclase activation (Gilman, 1984). For this reason, the blocking capacity of cholate extracts from $T$. cruzi membranes treated with pertussis toxin and $\mathrm{NAD}^{+}$was also examined. Under the selected conditions, the putative polypeptide acceptor seemed to be fully ADP- ribosylated. As shown in Fig. 2, extracts from untreated membranes, but not from toxin-treated membranes, blocked glucagon stimulation of adenylate cyclase activity in liver membranes. This strongly suggests the involvement of a $T$. cruzi $\mathrm{G}_{\alpha \mathbf{1}}$ protein in this effect.

\section{ADP-ribosylation with pertussis toxin}

ADP-ribosylation catalysed by Bordetella pertussis toxin has been used for specific identification of $\mathrm{G} \alpha_{i}, \mathrm{G} \alpha_{\mathrm{t}}$ and $\mathrm{G} \alpha_{\mathrm{o}}$ subunits in crude membranes (Gilman, 1984). Consequently, T. cruzi membranes were incubated with activated pertussis toxin plus [adenylate ${ }^{32} \mathrm{P}_{\mathrm{NAD}}$, and the incorporation of radioactivity into a trichloroacetic acid-insoluble product was determined. As shown in Fig. 3, after resolution of membrane polypeptides by SDS/PAGE a labelled product was detected with an electrophoretic mobility slightly slower than that of ADP-ribosylated transducin. The apparent molecular mass of this product was approx. $43 \mathrm{kDa}$.

On the other hand, the incorporation was dependent on the presence of this toxin and could be displaced by addition of unlabelled $\mathrm{NAD}^{+}$(results not shown).

\section{Characterization with specific antisera}

Further characterization of the putative $T$. cruzi $\mathrm{G}_{1}$ protein was performed by analysis of membrane polypeptides by Western blotting and further reaction with antisera raised against synthetic peptides corresponding to conserved sequences of G-protein subunits. Reaction with GA/1 (anti- $\alpha_{\text {common }}$ ) or with AS/7 (anti$\alpha_{t}$, anti- $\alpha_{11}$ and anti- $\alpha_{12}$ ) polyclonal antibodies led to the identification of specific polypeptide bands with mobilities corresponding to about $43 \mathrm{kDa}$ (Figs. $4 a, 4 b$ and $4 c$ ). In contrast, the $\mathrm{RM} / 1$ antibody $\left(\right.$ anti- $\left.\alpha_{\mathrm{s}}\right)$ revealed a polypeptide band of about $46 \mathrm{kDa}$ (Fig. $4 d$ ), which is similar to that previously reported by this laboratory for the cholera-toxin ADPribosylated polypeptide (Eisenschlos et al., 1986).

On the other hand, the reaction of membrane polypeptides with the SW/1 (anti- $\beta$ ) antibody revealed a specific polypeptide band with a mobility corresponding to about $30 \mathrm{kDa}$ (Fig. 4e). The size of this $\mathrm{G} \beta$-like polypeptide is smaller than those of the two types of $\beta$ subunits identified in higher eukaryotic organisms, with molecular masses of approx. 35-36 kDa (Birnbaumer et al., 1990).

Results in the present paper indicate the presence in $T$. cruzi

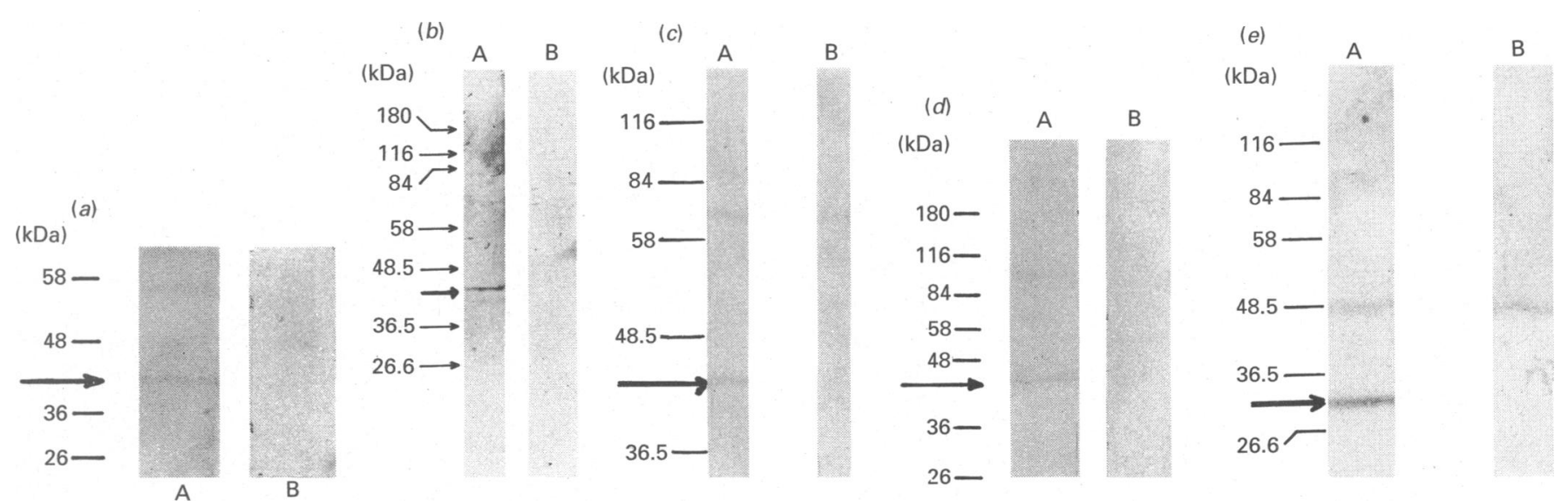

Fig. 4. Immunoreaction of $T$. cruzi membrane polypeptides with antisera directed against G-protein subunits: (a) GA/1; (b) and (c) AS/7; (d) RM/1; (e) $\mathrm{SW} / 1$

Lanes A and B respectively show reaction with the specific antisera and the result of control reactions performed with preimmune serum ( $a$, $b$, $d$ and $e$ ); in $c$, the control was performed by blockage of the antiserum with the specific peptide. Conditions for gel electrophoresis, blotting and competition with the peptide are given in the Materials and methods section. 
membranes of a polypeptide of the $\alpha_{t} / \alpha_{i 1,2}$ type which can be ADP-ribosylated in the presence of $\mathrm{NAD}^{+}$and preactivated pertussis toxin. This polypeptide may be a part of a heteromultimeric protein of the G-family, since the presence in the same membrane fraction of a polypeptide having the epitope characteristic of $\mathrm{G} \beta$ subunit was also detected. As occurs with mammalian $\mathrm{G}_{\mathrm{i}}$-proteins, this Trypanosomatidae membrane component was able to block hormone stimulation of liver membrane adenylate cyclase activity in heterologous reconstituted systems.

These results provide the first indication of the existence of $\mathrm{G}_{\mathrm{i}}$ like proteins in lower eukaryotic organisms. This fact, together with the previous description of an $\alpha_{\mathrm{s}}$-like polypeptide in $T$. cruzi membranes (Eisenschlos et al., 1986) indicates that Trypanosomatidae, like animal tissues, have a well-developed set of Gproteins that may be associated with membrane transduction mechanisms. In vivo, this transduction mechanism may be precisely the regulation of adenylate cyclase activity by a receptor whose hormone has not yet been identified.

H.N.T. and M.M.F. are career members of the Consejo Nacional de Investigaciones Científicas y Técnicas (CONICET); J.P.M., A. D. A. and O.A.C. are fellows of CONICET, University of Buenos Aires and Comisión de Investigaciones Científicas, Provincia de Buenos Aires (Argentina) respectively. This work was partially supported by the TDR Programme, World Health Organization and by Fundación Antorchas (Argentina).

\section{REFERENCES}

Birnbaumer, L., Abramowitz, J. \& Brown, A. M. (1990) Biochim. Biophys. Acta 1031, 163-224

Received 28 February 1992/27 April 1992; accepted 30 April 1992
Burstein, E. \& Macara, I. G. (1989) Mol. Cell. Biol. 9, 4807-4811

Eisenschlos, C. D., Paladini, A. A., Molina y Vedia, L., Torres, H. N. \& Flawiá, M. M. (1986) Biochem. J. 237, 913-917

Flawiá, M. M., Kornblihtt, A. R., Reig, J. M., Torruella, M. \& Torres, H. N. (1983) J. Biol. Chem. 247, 6873-6879

Gilman, A. G. (1984) Cell 36, 577-579

Goldsmith, P., Backlund, P. S., Rossiter, K., Carter, A., Milligan, G., Unson, C. G. \& Spiegel, A. M. (1988) Biochemistry 27, 7085-7090

Holz, G. G., Rane, S. G. \& Dunlap, K. (1986) Nature (London) 319, 670-672

Jakobs, K. H., Saur, W. \& Schultz, G. (1976) J. Cyclic Nucleotide Res. 2, 381-392

Johnson, D. A., Gautsch, J. W., Spotsman, J. R. \& Elder, J. H. (1984) Gene Anal. Tech. 1, 3-8

Khyse-Andersen, J. (1984) J. Biochem. Biophys. Methods 10, 203-209

Kornblihtt, A. R., Flawiá, M. M. \& Torres, H. N. (1981) Biochemistry 20, 1262-1267

Kurachi, Y., Nakajima, T. \& Sugimoto, T. (1986) Pfluegers Arch. 407, 264-274

Lowry, O. H., Rosebrough, N. J., Farr, A. L. \& Randall, R. J. (1951) J. Biol. Chem. 193, 265-275

Mumby, S. M., Kahn, R. A., Manning, D. R. \& Gilman, A. G. (1986) Proc. Natl. Acad. Sci. U.S.A. 83, 265-269

Muschietti, J. P., Bianchini, G. M., Martinetto, H. E., Carricarte, V. C., Giusto, N., Farber, D. B., Torres, H. N. \& Flawiá, M. M. (1989) Eur. J. Biochem. 185, 205-210

Neville, D. M. (1968) Biochim. Biophys. Acta 164, 540-544

Northup, J. K., Smigel, J. M. \& Gilman, A. G. (1982) J. Biol. Chem. 257, $11416-11423$

Simonds, W. F., Goldsmith, P. K., Codina, J., Unson, C. G. \& Spiegel, A. M. (1989) Proc. Natl. Acad. Sci. U.S.A. 86, 7809-7813

Stryer, L. (1986) Annu. Rev. Neurosci. 9, 87-119

Torruella, M., Flawiá, M. M., Eisenschlos, C., Molina y Vedia, L., Rubinstein, C. \& Torres, H. N. (1986) Biochem. J. 234, 145-150

Waldo, G. L., Evans, T., Fraser, E. D., Northup, J. K., Martin, M. W. \& Hardern, T. K. (1987) Biochem. J. 246, 431-439

Yatani, A., Codina, J., Sekura, R. D., Birnbaumer, L. \& Brown, A. M. (1987) Science 238, 1288-1292 